\title{
Clinical Audit on Management of Hematemesis in Children Admitted to Pediatric Gastroenterology and Hepatology Unit of Assiut University Children Hospital
}

\author{
ESRAA T. AHMED, M.Sc.; FATMA A. ALI, M.D. and NAGLA H. ABU FADDAN, M.D. \\ The Department of Pediatrics, Faculty of Medicine, Assiut University, Assiut, Egypt
}

\begin{abstract}
Background: Hematemesis is an uncommon but potentially serious and life-threatening clinical condition in children. It indicates that the bleeding origin is above the Treitz angle, i.e., that it constitutes an Upper Gastrointestinal Bleeding (UGIB).
\end{abstract}

Aim of Study: To assess for how much the adopted protocols of management of children with upper gastrointestinal bleeding were applied at Gastroenterology \& Hepatology Unit of Assiut University Children Hospital.

Patients and Methods: This study is a an audit on management of children with upper gastrointestinal bleeding admitted to pediatric Gastroenterology and Hepatology Unit, Assiut University Children Hospital during the period from the 1 st of March 2016 to the 28 th of February 2017 and it included 80 children with hematemesis.

Results: Detailed history intake was recorded in most cases except history of drug intake which was not recorded in $30 \%$ of cases, history of epigastric pain and food pain relationship were not recorded in $38.7 \%$ of cases. Data of examination were recorded in $100 \%$ of cases. Basic and mandatory investigations in diagnosis of hematemesis were done in $100 \%$ of cases except coagulation profile and liver function tests and upper endoscopy. The standard treatment of hematemesis has been applied in most treatment lines except admission to the Intensive Care Unit. Also intravenous vitamin $\mathrm{K}$ was not given to all patients.

Conclusion: The international guidelines for the management of hematemesis have been followed by the Gastroenterology and Hepatology Unit of Assiut University Children Hospital in most treatment lineswith some defaults due to poor resources and lack of medication.

Key Words: Hematemesis - Pediatrics.

\section{Introduction}

UPPER Gastrointestinal Bleeding (UGIB) is an uncommon but potentially serious and lifethreatening clinical condition in children $[1,2]$.

Correspondence to: Dr. Esraa T. Ahmed,

E-Mail: esraatalaat96@gmail.com
Hematemesis: Indicates that the bleeding origin is above the Treitz angle, i.e., that it constitutes an Upper Gastrointestinal Bleeding (UGIB) [3] .

The etiology of upper GI bleeding varies by age. The pathophysiology of upper GI bleeding is related to the source of the bleeding. Most clinically significant causes of upper GI bleeds are associated with ulcers, erosive esophagitis, gastritis, varices, and/or Mallory-Weiss tears. While Physiologic stress, NSAIDs such as aspirin and ibuprofen, and infection with Helicobacter pylori are few of the factors contributing to the imbalance leading to ulcers and erosions in the GI tract [4].

A focused history and physical examination and vital signs targeted at elucidating potential causes of bleeding should be rapidly obtained. Children with a history of concurrent major illness that require PICU care, such as sepsis and respiratory failure, may present with stress gastritis or stress ulcers [5].

Blood should be obtained to measure hemoglobin, hematocrit, blood urea nitrogen, creatinine, platelet count, prothrombin and partial thromboplastin times, international normalized ratio, liver enzymes, crossmatch, electrolytes and hepatitis markers. Abdominal US and Upper Endoscopy are important for investigation [6]

Management of a child with hematemesisincludes: Resuscitation and stabilization, correction of coagulopathies, pharmacotherapy and urgent endoscopy [1]

\section{Patients and Methods}

The present study was conducted in Assiut University Children Hospital on all children with hematemesis admitted to Gastroenterology \& Hepa- 
tology Unit during the period from the 1 st of March 2016 to the 28 th of February 2017 and it included 80 children.

The following items were taken:

A- History:

- History of recent or recurrent epistaxis.

- History of recent onset of jaundice.

- History of change in stool color.

- History of easy bruising or bleeding from other orifices.

- History of liver disease.

- History of epigastric pain, food pain relationship.

- History of recent medications ingested (such as NSAIDs and corticosteroids).

- History of previousattack of hematemesis.

\section{B- Examination:}

- General examination:

- Conscious level.

- Jaundice, pallor, cyanosis.

- Fetor hepaticus.

- Vital signs:

- Pulse.

- Blood pressure.

- Temperature.

- Respiratory rate.

- Skin-petechiae for liver cell failure disease like Palmar erythema, spider nevi.

- Chest examination.

- Cardiac examination.

- Abdominal examination:

- Hepatomegaly.

- Splenomegaly.

- Ascites.

C- Investigations:

- Complete blood count.

- Prothrombin time, prothrombin concentration.

- Liver function tests.

- Kidney function tests and electrolytes.

- Hepatitis markers.

- Abdominal ultrasound.

- Upper endoscopy.
D- Treatment:

- Admission at Intensive Care Unit.

- Resuscitation and stabilization by: Large bore venous access, crystalloid initially, blood transfusion and insertion of nasogastric tube.

- Correction of Coagulopathies: Vitamin K given empirically and Fresh Frozen Plasma (FFP).

- Pharmacotherapy: Octreotide in cases of Variceal bleed, Beta Blocker, PPI or H2 blocker in cases of Mucosal bleeding.

- Endoscopic techniques in cases of variceal bleeding: Endoscopic Variceal ligation alone and Endoscopic Sclerotherapy + Variceal ligation.

\section{Inclusion criteria:}

Children from 1 month to 18 years with hematemesis.

\section{Results}

The present study included 80 children with hematemesis who were admitted to Gastroenterology \& Hepatology Unit of Assiut University Children Hospital over one year period from the 1 st of March 2016 to the 28 th of February 2017, 43 cases were males and 37 cases were females with age range from 1 month to 18 years.

The results of the present study are shown in (Tables 1-5).

Table (1): Findings of history in studied children (total number $=80$ ).

\begin{tabular}{lllll}
\hline & \multicolumn{3}{c}{ Yes } & \multicolumn{2}{c}{ No } \\
\cline { 2 - 5 } & No. & $\%$ & No. & $\%$ \\
\hline - Recent or recurrent epistaxis. & 13 & 16.3 & 67 & 83.7 \\
- Recent onset of jaundice. & 18 & 22.5 & 62 & 77.5 \\
- Recent onset of change in stool color. & 25 & 31.2 & 55 & 68.8 \\
- History of easy bruising or bleeding from & 15 & 18.8 & 65 & 81.2 \\
other orifices. & & & & \\
- History of liver disease. & 24 & 30 & 56 & 70 \\
- Liver cirrhosis. & 9 & 37.5 & & \\
- Extrahepatic biliary atresia. & 2 & 8.3 & & \\
- Portal vein thrombosis. & 6 & 25.0 & & \\
- Wilson disease. & 2 & 8.3 & & \\
- Autoimmune hepatitis. & 1 & 4.2 & & \\
- Hepatitis C. & 1 & 4.2 & & \\
- Congenital liver fibrosis. & 1 & 4.2 & & \\
- Alpha-1 antitrypsin deficiency. & 1 & 4.2 & & \\
- TORCH hepatitis. & 1 & 4.2 & & \\
- Epigastric pain, food pain relationship. & 17 & 34.7 & 32 & 65.3 \\
- History of recent medications ingested & 7 & 12.5 & 49 & 87.5 \\
(NSAID, Corticosteroid). & & & & \\
- History of previous attack of hematemesis. & 34 & 42.5 & 46 & 57.5 \\
- History of vomiting. & 26 & 32.5 & 54 & 67.5 \\
\hline
\end{tabular}


Table (2): Findings of examination in studied children.

\begin{tabular}{|c|c|c|c|c|}
\hline & \multicolumn{2}{|c|}{ Yes } & \multicolumn{2}{|c|}{ No } \\
\hline & No. & $\%$ & No. & $\%$ \\
\hline $\begin{array}{l}\text { General examination: } \\
\text { Disturbed conscious level: } \\
\quad \text { Mild (GCS }=13-15) \\
\text { Moderate }(\mathrm{GCS}=9-12) \\
\text { Severe }(\mathrm{GCS}=3-8)\end{array}$ & $\begin{array}{l}18 \\
15 \\
2 \\
1\end{array}$ & $\begin{array}{l}22.5 \\
83.3 \\
11.1 \\
5.6\end{array}$ & 62 & 77.5 \\
\hline Pallor & 53 & 66.3 & 27 & 33.7 \\
\hline Jaundice & 18 & 22.5 & 62 & 77.5 \\
\hline Palmar erythema, spider nevi & 11 & 13.8 & 69 & 86.2 \\
\hline $\begin{array}{l}\text { Pulse: } \\
\text { Tachycardia } \\
\text { Normal pulse }\end{array}$ & $\begin{array}{l}17 \\
63\end{array}$ & $\begin{array}{l}21.3 \\
78.7\end{array}$ & & \\
\hline $\begin{array}{l}\text { Temperature: } \\
\text { Hyperthermia } \\
\text { Normal temperature }\end{array}$ & $\begin{array}{l}9 \\
71\end{array}$ & $\begin{array}{l}11.3 \\
88.7\end{array}$ & & \\
\hline $\begin{array}{l}\text { Blood pressure: } \\
\text { Hypotension } \\
\text { Normal blood pressure }\end{array}$ & $\begin{array}{l}7 \\
73\end{array}$ & $\begin{array}{l}8.8 \\
91.2\end{array}$ & & \\
\hline $\begin{array}{l}\text { Respiratory rate: } \\
\text { Tachypnea } \\
\text { Normal respiratory rate }\end{array}$ & $\begin{array}{l}13 \\
67\end{array}$ & $\begin{array}{l}16.3 \\
83.7\end{array}$ & & \\
\hline $\begin{array}{l}\text { Chest examination: } \\
\text { Respiratory distress, fine crepetations } \\
\text { Normal chest examination }\end{array}$ & $\begin{array}{l}3 \\
77\end{array}$ & $\begin{array}{l}3.7 \\
96.3\end{array}$ & & \\
\hline $\begin{array}{l}\text { Heart examination: } \\
\quad \text { Normal heart examination }\end{array}$ & 80 & 100 & & \\
\hline $\begin{array}{l}\text { Abdominal examination: } \\
\text { Ascites } \\
\text { Hepatomegaly } \\
\text { Splenomegaly }\end{array}$ & $\begin{array}{l}8 \\
24 \\
13\end{array}$ & $\begin{array}{l}10 \\
30 \\
16.3\end{array}$ & $\begin{array}{l}72 \\
56 \\
67\end{array}$ & $\begin{array}{l}90 \\
70 \\
83.7\end{array}$ \\
\hline
\end{tabular}

Table (3): Findings of investigations in studied children.

\begin{tabular}{|c|c|c|}
\hline Investigations & No. & $\%$ \\
\hline \multicolumn{2}{|l|}{ Complete blood count (CBC): } & \\
\hline Range & \multicolumn{2}{|c|}{$3.1-33.1$} \\
\hline Mean \pm SD & \multicolumn{2}{|c|}{$10.91 \pm 6.63$} \\
\hline - Leukocytosis & 29 & 36.3 \\
\hline - Normal leukocytic count & 51 & 63.7 \\
\hline \multicolumn{3}{|l|}{ Haemoglobin level: } \\
\hline Range & \multicolumn{2}{|c|}{$\begin{array}{c}4.5-13 \\
937+2.18\end{array}$} \\
\hline Mean \pm SD & \multicolumn{2}{|c|}{$9.37 \pm 2.18$} \\
\hline - Anemia & 58 & 72.5 \\
\hline - Normal haemoglobin level & 22 & 27.5 \\
\hline \multicolumn{3}{|l|}{ Platelet count: } \\
\hline Range & \multirow{2}{*}{\multicolumn{2}{|c|}{$\begin{array}{c}34-627 \\
277.66 \pm 144.07\end{array}$}} \\
\hline Mean \pm SD & & \\
\hline - Thrombocytopenia & 11 & 13.8 \\
\hline - Thrombocytosis & 12 & 15.0 \\
\hline - Normal platelet count & 57 & 71.2 \\
\hline \multicolumn{3}{|c|}{$\begin{array}{l}\text { Prothrombin time }(P T), \text { prothrombin } \\
\text { concentration }(P C) \text { : }\end{array}$} \\
\hline - Prolonged PT, PC & 17 & 25.4 \\
\hline - Normal PT, PC & 50 & 74.6 \\
\hline \multicolumn{3}{|l|}{ Liver function tests: } \\
\hline \multicolumn{3}{|l|}{ Bilirubin level: } \\
\hline - Hyper bilirubinemia & 18 & 29.0 \\
\hline - Normal bilirubin level & 44 & 71.0 \\
\hline
\end{tabular}

Table (3): Findings of investigations in studied children (Continue).

\begin{tabular}{|c|c|c|}
\hline Investigations & No. & $\%$ \\
\hline $\begin{array}{l}\text { Liver enzymes }(A L T, A S T) \text { : } \\
\quad \text { - Raised liver enzymes } \\
\text { - Normal liver enzymes }\end{array}$ & $\begin{array}{l}16 \\
46\end{array}$ & $\begin{array}{l}25.8 \\
74.2\end{array}$ \\
\hline $\begin{array}{l}\text { Kidney function tests: } \\
\text { - Raised kidney function tests } \\
\text { - Normal kidney function tests }\end{array}$ & $\begin{array}{l}2 \\
78\end{array}$ & $\begin{array}{l}2.5 \\
97.5\end{array}$ \\
\hline $\begin{array}{l}\text { Electrolytes: } \\
\text { Na (Sodium): } \\
\text { Hypernatremia } \\
\text { Hyponatremia } \\
\text { Normal Na level }\end{array}$ & $\begin{array}{l}3 \\
8 \\
69\end{array}$ & $\begin{array}{l}3.7 \\
10 \\
86.3\end{array}$ \\
\hline $\begin{array}{l}K \text { (Potassium }): \\
\text { Hyperkalemia } \\
\text { Hypokalemia } \\
\text { Normal K level }\end{array}$ & $\begin{array}{l}1 \\
4 \\
75\end{array}$ & $\begin{array}{l}1.2 \\
5 \\
93.8\end{array}$ \\
\hline $\begin{array}{l}\text { Ca }(\text { Calcium }): \\
\text { Hypercalcemia } \\
\text { Hypocalcemia } \\
\text { Normal Ca level }\end{array}$ & $\begin{array}{l}0 \\
7 \\
73\end{array}$ & $\begin{array}{l}0 \\
8.7 \\
91.3\end{array}$ \\
\hline $\begin{array}{l}\text { Hepatitis markers: (Indicated cases }=13 \text { ) } \\
\text { Hepatitis A virus antibody IgM: +ve } \\
\text { Hepatitis C virus antibody: +ve } \\
\text { Negative hepatitis markers }\end{array}$ & $\begin{array}{l}6 \\
1 \\
6\end{array}$ & $\begin{array}{l}46.2 \\
7.6 \\
46.2\end{array}$ \\
\hline $\begin{array}{l}\text { Abdominal ultrasound findings: } \\
\text { Hepatomegaly } \\
\text { Splenomegaly } \\
\text { Ascites }\end{array}$ & $\begin{array}{l}24 \\
13 \\
8\end{array}$ & $\begin{array}{l}30 \\
16.3 \\
10\end{array}$ \\
\hline $\begin{array}{l}\text { Upper endoscopy: } \\
\text { Oesophageal varices } \\
\text { Gastritis } \\
\text { Duodenitis } \\
\text { Gastroduodenitis } \\
\text { Mallory Weiss syndrome } \\
\text { GERD } \\
\text { Normal endoscopic finding }\end{array}$ & $\begin{array}{l}24 \\
21 \\
20 \\
4 \\
3 \\
1 \\
5\end{array}$ & $\begin{array}{l}30.8 \\
26.9 \\
25.7 \\
5.1 \\
3.8 \\
1.3 \\
6.4\end{array}$ \\
\hline
\end{tabular}

Table (4): Treatment of all studied children.

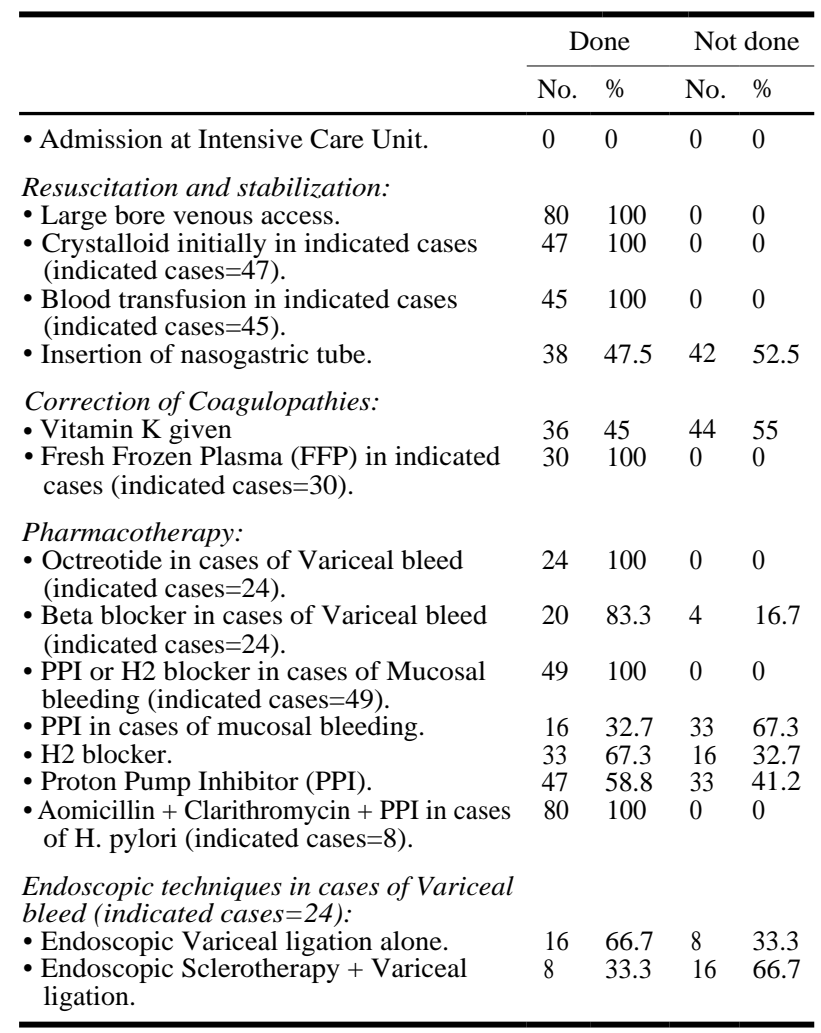


Table (5): Findings in children presented with hematemsis.

\begin{tabular}{llll}
\hline The findings & Male $(\mathrm{n}=43)$ & Female $(\mathrm{n}=37)$ & Total $(\mathrm{n}=80)$ \\
\hline Esophageal varices & $15(62.5 \%)$ & $9(37.5 \%)$ & $24(30 \%)$ \\
Gastritis & $7(33.3 \%)$ & $14(66.7 \%)$ & $21(26.3 \%)$ \\
Duodenitis & $10(50 \%)$ & $10(50 \%)$ & $20(25 \%)$ \\
Gastroduodenitis (gastritis and duodenitis) & $2(50 \%)$ & $2(50 \%)$ & $4(5 \%)$ \\
Mallory Weiss syndrome & $3(100 \%)$ & - & $3(3.8 \%)$ \\
Glanzeman thrombathenia & $2(66.7 \%)$ & $1(33.3 \%)$ & $3(3.8 \%)$ \\
Milk protein allergy & $2(100 \%)$ & $1(2.5 \%)$ & $1(1.2 \%)$ \\
Gastroesophageal reflux disease (GERD) & $1(100 \%)$ & - & $1(1.2 \%)$ \\
Swallowed blood syndrome & $1(100 \%)$ & $1(100 \%)$ & $1(1.2 \%)$ \\
Thrombathenia secondary to NSAID & &
\end{tabular}

\section{Discussion}

Regarding history taking; most data of the history were fulfilled except history of drug intake (NSAIDS and Corticosteroids) which was recorded in $70 \%$ of cases, history of epigastric pain and food pain relationship which were recorded in $61.3 \%$ of cases.

Many prescription and medications have been associated with gastritis, peptic ulcer and dudenitis [4]. Therefore, it is important to take into consideration the importance of history of drug intake in children with hematemsis. Unless the underlying liver disease is successfully treated, hematemsis is associated with a high risk of recurrence [1].

Regarding examination; in the present study all data of examination were fulfilled in $100 \%$ of cases.

Regarding investigations; most recommended investigations were done except coagulation profile which was done in $83.7 \%$ of cases and liver function tests which were done in $77.5 \%$ of cases in whomit was suspected that hepatic disorder was the cause of hematemesis. Upper endoscopy was done in $97.5 \%$ of cases (survivded cases). Elevated liver enzymes may indicate underlying liver disease and prolonged PT/INR or PTT may indicate preexisting coagulopathy. Hepatitis markers were done in cases that were suspected to have hepatitis and not in other cases that had a known cause as billiary atresia or portal vein thrombosis. So they were done in $100 \%$ of indicated cases. Upper gastrointestinal endoscopy is the gold standard for diagnosis and treatment of UGIB and this procedure can diagnose the etiology in $85-90 \%$ of cases. It is indicated to identify the site of the bleeding, to diagnose the specific cause of the bleeding, and to initiate therapeutic interventions when indicated. If endoscopic appearance suggests esophagitis, gastritis or duodenitis a biopsy should be obtained; in suspected peptic ulcer disease antral biopsies for H. pylori work up (histological examination, rapid urease test, and culture) should be taken. Though there is no definite time frame given, in all cases of major upper GI bleed, an early endoscopy (within first $24 \mathrm{~h}$ ) is recommended by most of the reviews [1]

Regarding treatment; the international guidelines for the management of hematemsis have been followed by the Gastroenterology and Hepatology Unit of Assiut University Children Hospital in most treatment lines except admission to the Intensive Care Unit, no case was admitted to Intensive Care Unit (instead they all were admitted at Gastroenterology Intermediate Care Unit) so, prophylactic endotracheal intubation was not applicable.

Owensby et al., reported that; patients with active bleeding that leads to hemodynamic compromise require intravenous access for fluid resuscitation and transfusion. Insertion of large bore venous access was done in $100 \%$ of cases to restore blood volume. Crystalloid $(20 \mathrm{ml} / \mathrm{kg}$ ) was given in $100 \%$ of indicated cases for fluid resuscitation in the cases of hypovolemia and shock [7]. Blood transfusion was given in $100 \%$ of indicated cases. Blood transfusion is appropriate for unstable patients and those with hemoglobin $<8 \mathrm{~g} / \mathrm{dL}$ [6]. A nasogastric tube placement and lavage should be considered for all pediatric patients with suspected upper GI bleeding $[\mathbf{7 , 8 ]}$.

Lavage allows for sampling of gastric contents to confirm the presence of blood, localizing bleeding to the upper GI tract, estimating the rate of bleeding, check for ongoing or recurrent bleeding, to clear gastric field for endoscopic visualization, to prevent aspiration of gastric contents and preventing hyperammonemia and hepatic encephalopathy in patients with liver disease [7]. Insertion of nasogastric tube and lavagewere done in $47.5 \%$ of our cases because not all cases presented with active bleeding, in some cases the bleeding stopped spontaneously, so there was no need in those children to insert nasogasric tube because there was no ongoing blood loss in that moment. Also na- 
sogastric tube was not inserted in children with suspected large oesophageal varices in this study because it is contraindicated, for fear of rupture of varices and increase risk of bleeding. Singhi et al., recommended that administration of intravenous vitamin $\mathrm{K}$ at a dose of 1 to $2 \mathrm{mg} / \mathrm{dose}$ for infants and 5 to $10 \mathrm{mg}$ for children as vitamin $\mathrm{K}$ is necessary for synthesis of clotting factors II, VII, IX, and X. In the present study only $45 \%$ of children who had prolonged PT and PC were given intravenous Vitamin K. Other children with normal coagulation profile did not recieve it. Our opinion for this, is that in the country with limited resources like us it is wise to limit the use of Vitamin $\mathrm{K}$ or other drugs to needed children only; not in all children who present with hematemesis especially that the outcome of other children was not affected by this lack of intake. Fresh Frozen Plasma (FFP) was given in $100 \%$ of indicated cases. Coagulopathy with an International Normalized Ratio (INR) higher than 1.5 or abnormal Partial Thromboplastin Time (PTT) should be corrected with fresh frozen plasma (10 $\mathrm{ml} / \mathrm{kg}$ initially). Octreotide was given in $100 \%$ of indicated cases (cases of variceal bleeding). It produces selective splanchnic vasoconstriction and decreases portal inflow, thereby indirectly reducing variceal blood flow, our data are in agreement with Romano et al., 3 -Blocker was given in $100 \%$ of indicated cases (cases of Variceal bleeding). It reduce portal pressuresby decreasing cardiac output and vasoconstrictingthe splanchnic vessels via blockade of $\beta-1$ and $\beta-2$ receptors [9] .

Proton Pump Inhibitors or $\mathrm{H}_{2}$ Receptor Antagonists were given in $100 \%$ of indicated cases of mucosal bleeding. Proton Pump Inhibitors (PPIs) are more efficacious than $\mathrm{H}_{2}$ receptor antagonists [7].

Endoscopic variceal ligation alone was done in $66.7 \%$ of cases (cases of variceal bleeding). Upper gastrointestinal endoscopy should be performed as soon as possible after initial stabilization. Endoscopic therapy should be done if variceal source of hemorrhage is confirmed [7]. In management of acute variceal bleeding, Endoscopic Variceal Ligation $(\mathrm{EVL})$ is the treatment of choice $[\mathbf{1 0 , 1 1 ]}$ Endoscopic variceal ligation and endoscopic sclerotherapy were done in $100 \%$ of indicated cases (cases of esophageal varices and fundal varices).

\section{Conclusion:}

The international guidelines for the management of hematemesis have been followed by the Gastro- enterology and Hepatology Unit of Assiut University Children Hospital in most treatment lines and some of thedefaults were due to poor resources.

\section{References}

1- OWENSBY S., TAYLOR K. and WILKINS T.: Diagnosis and management of upper gastrointestinal bleeding in children. J. Am. Board Fam. Med., 28 (1): 134-45, 2015.

2- CLEVELAND K., AHMAD N., BISHOP P. and NOWICKI M.: Upper gastrointestinal bleeding in children: An 11-year retrospective endoscopic investigation. World J. Pediatric, 8: 123-8, 2012.

3- De CARVALHO E., H. NITA M., LILIANE M.A. PAIVA and ANA AURÉLIA R. SILVA: Gastrointestinal bleeding (UGIB). Jornal de Pediatria-Vol. 76, Supl. 2, 135-S146, 2000.

4- HUANG S.C., SHEU B.S., LEE S.C., YANG H.B. and YANG Y.J.: Etiology and treatment of childhood peptic ulcer disease in Taiwan: A single center 9-year experience. J. Formos Med. Assoc., 109 (1): 75-81, 2010.

5- DUCHE M., DUCOT B., TOURNAY E., FABRE M., COHEN J., JACQUEMIN E., et al.: Prognostic value of endoscopy in children with biliary atresia at risk for early development of varices and bleeding. Gastroenterology, 139: 1952-60, 2010.

6- COLLE I., WILMER A., Le MOINE O., DEBRUYNE R., DELWAIDE J., DHONDT E., et al.: Upper gastrointestinal tract bleeding management: Belgian guidelines for adults and children. Acta Gastroenterol. Belg., 74: 45-66, 2011.

7- SINGHI S., JAIN P., JAYASHREE M. and LAL SADHNA: Approach to a child with upper gastrointestinal bleeding. Indian J. Pediatr., 80 (4): 326-33, 2013.

8- CARCILLO J.A. and FIELDS A.I.: Clinical practice parameters for hemodynamic support of pediatric and neonatal patients in septic shock. Crit. Care Med., 30: 1365-78, 2000.

9- ROMANO C., OLIVA S., MARTELLOSSI S., MIELE E., ARRIGO S., GRAZIANI M.G., et al.: Pediatric gastrointestinal bleeding: Perspectives from the Italian Society of Pediatric Gastroenterology. World J. Gastroenterol., 23 (8): 1328-37, 2017.

10- DAI C., LIU W.X., JIANG M. and SUN M.J.: Endoscopic variceal ligation compared with endoscopic injection sclerotherapy for treatment of esophageal variceal hemorrhage: A meta-analysis. World J. Gastroenterol., 21: 2534-41, 2015.

11- SHNEIDER B.L., BOSCH J., De FRANCHIS R., EMRE S.H., GROSZMANN R.J., LING S.C., et al.: Portal hypertension in children: Expert pediatric opinion on the report of the Baveno v Consensus Workshop on Methodology of Diagnosis and Therapy in Portal Hypertension. Pediatr. Transplant., 16: 426-37, 2012. 


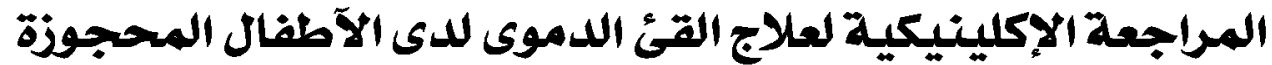

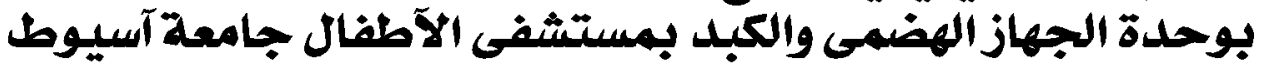

القئ الدموى: هو نزيف بالجهاز الهضمى العلوى آعلى رباط ترينز الذى يقع فى الثنية الإثناعثرية الصائمية. ويتميز القئ باللون الآحمر

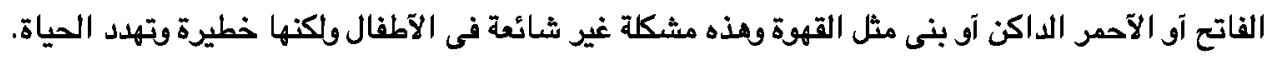

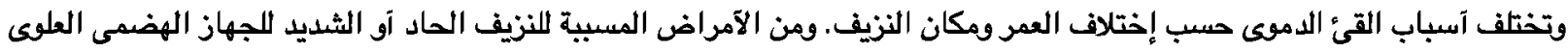

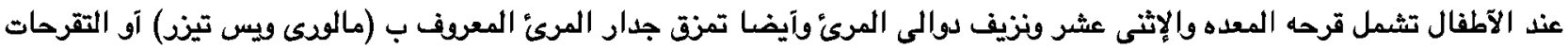

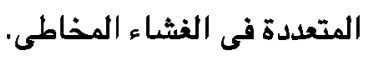

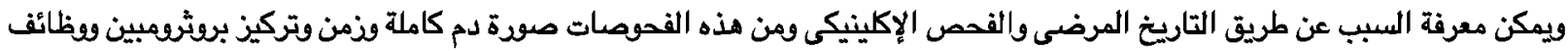

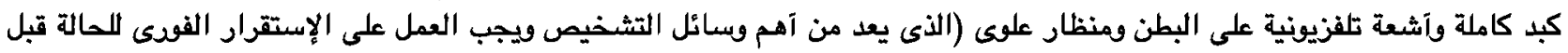

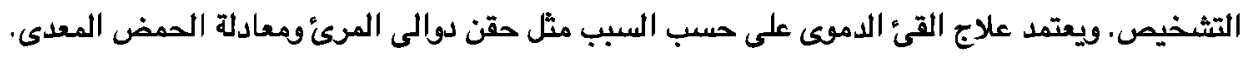

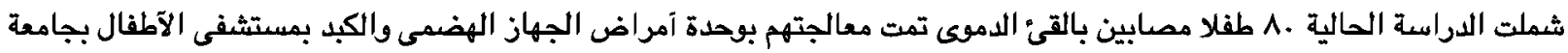

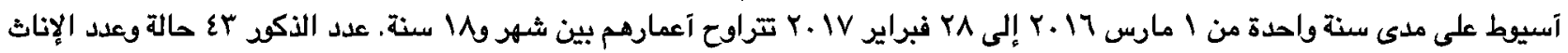

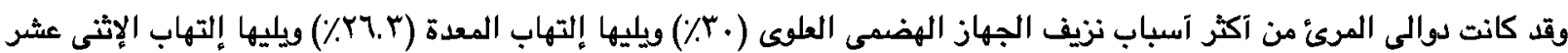

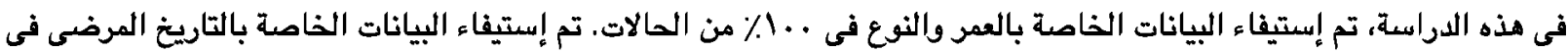

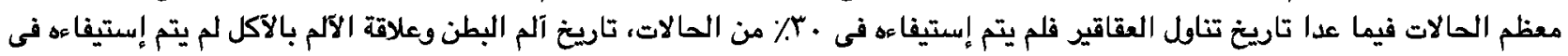

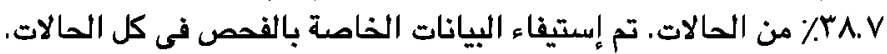

وقد تم إستيفاء البيانات الخاصة بالتحاليل المعملية الآساسية اللازمة لتشخيص القئ الدموى فى كل الحالات ما عدا فحص تخثر الدم ووظائف الكبد.

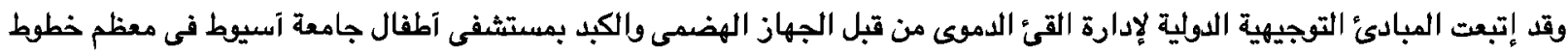

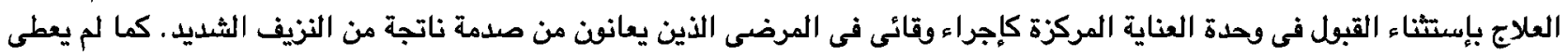

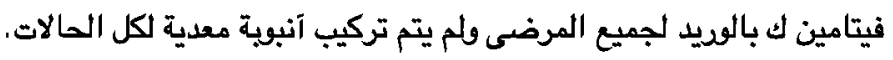

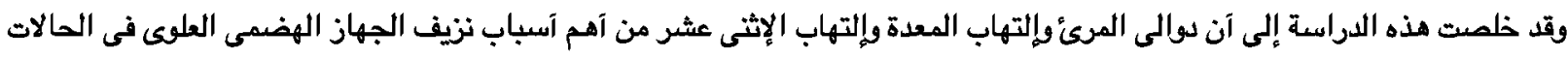

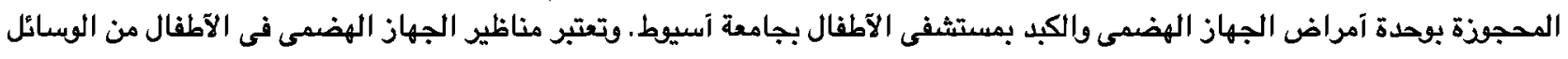

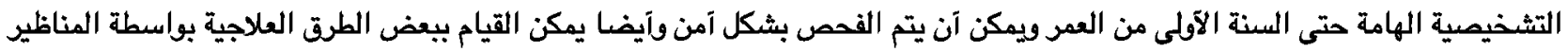

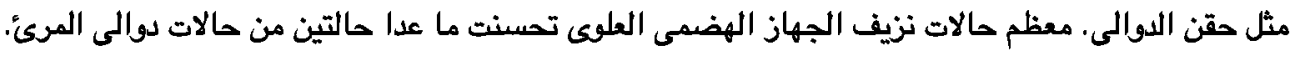

وينصح بالآنى: • يجب القيام جميع المرضى الذين يعانفن من القئ الدموى واللذين تم حجزهم بالمستثفى وإعطاء الآولوية لإستقرار الحالة قبل البحث عن الإنمان

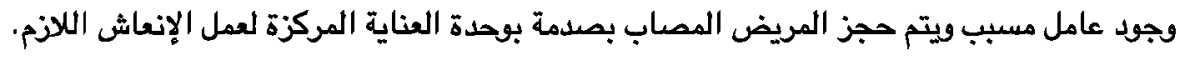

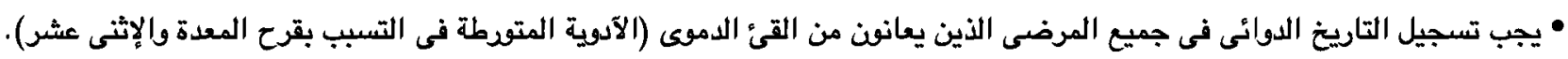

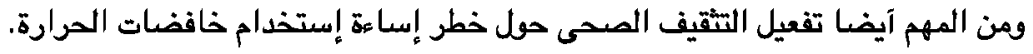

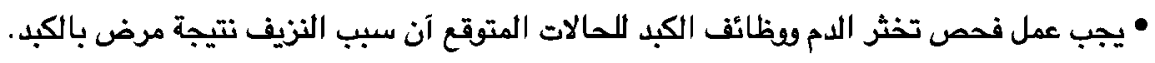

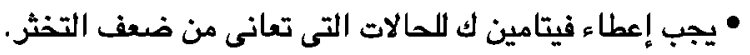
• يجب تركيب الآنبوبة المعدية بآيدى متدرية فى حالات النى من فلعيف المستمر. 